\title{
Seroprevalence of Visna-Maedi Virus (VMV) and Border Disease Virus (BDV) in Van province and around
}

\author{
[Seroprevalência de Visna-Maedi Virus (VMV) e Border Disease Virus (BDV) na \\ Província de Van e Proximidades] \\ P.S. Mohammad Ameen ${ }^{1}$, Z. Karapınar ${ }^{2 *}$ \\ ${ }^{1}$ University of Yuzuncu Yil - Faculty of Veterinary - Department of Microbiology-Van, Turkey \\ ${ }^{2}$ University of Balıkesir - Faculty of Veterinary - Department of Virology- Balıkesir, Turkey
}

\begin{abstract}
The present study investigated the seroprevalance of Visna Maedi Virus (VMV) and Border Disease Virus (BDV) infections in sheeps in regions in and around Van province, Turkey. Sample materials were taken from 360 sheep sent to slaughterhouses around Van. All serum samples were examined using ELISA for antibodies for Visna Maedi (VMV) and Border Disease (BDV) viruses. Of these, 38 (10.5\%) tested positive for Visna Maedi virus antibodies and 163 (45.2\%) for Border Disease virus antibodies. Varying numbers of samples were positive for both virus antibodies across the towns of Erciş, Çaldıran, Erçek and Başkale in Van, Ağrı and Hakkari provinces. Both infections should be eliminated by informing veterinarians and animal owners, identifying and eliminating persistently infected animals from flocks, and conducting appropriate eradication measures. Economic support should be provided for this.
\end{abstract}

Keywords: VMV, BDV, prevalence, Van

\section{RESUMO}

O presente estudo investigou a seroprevalência de infecções por Visna Maedi Virus (VMV) e Border Disease Virus (BDV) em ovelhas nas redondezas da província de Van, na Turquia. Amostras foram retiradas de 360 ovelhas enviadas a um matadouro próximo de Van. Todas as amostras foram examinadas usando ELISA para anticorpos de visna Maedi (VMW) e Border Disease (BDV). Destes, 38 (10.5\%) foram positivos para anticorpos virais de Visna Maedi e 163 (45.2\%) para anticorpos virais de Border Disease. Números variados de amostras foram positivos para ambos os anticorpos nos municípios de Erciş, Çaldıran, Erçek e Başkale, nas províncias Van, Ağrı e Hakkari. Ambas as infecções devem ser eliminadas informando veterinários e proprietários, identificando e eliminando animais persistentemente infectados de rebanhos, e conduzindo medidas apropriadas de erradicação. Suporte financeiro deve ser providenciado para tal.

Palavras-chave: VMV, BDV, prevalência, Van

\section{INTRODUCTION}

Visna and Maedi are two disease manifestations in sheep caused by a lentivirus sub-family of the Retrovirus family, related to human, simian, feline, and bovine immunodeficiency viruses, equine infectious anaemia virus and caprine arthritis-encephalitis (CAE) virus (Peterhans et al., 2004). Visna-Maedi Virus (VMV) has a very long incubation period and so it may be years

Recebido em 7 de junho de 2017

Aceito em 30 de junho de 2017

*Autor para correspondência (corresponding author)

E-mail: zeynepkarapinar@gmail.com from the time of initial contact between the host and the infectious agent until the first clinical signs are seen. The earliest sign in Maedi is loss of body condition, tachypnea and arthritis. The early signs of Visna infection, which occurs much less commonly than Maedi, are muscle quivering and loss of balance in the rear quarters (Reina et al., 2009).

The VMV virion is $70-100 \mathrm{~nm}$ in diameter. The single-stranded positive RNA genome is reverse transcribed to DNA with reverse transcriptase 
(Thormar, 2013). Free virus or virus-infected cells are horizontally transmitted by inhalation of respiratory secretions, primarily because both cell-free virus and cell-associated virus are found in the bronchial alveolar fluid of infected sheep (McNeilly et al., 2008). Vertical transmission has been detected in the colostrum and milk of sheep, enabling maternal transmission from dam to progeny and non-maternal transmission through aerosolization of milk during dairy operations. Infected animals become persistently infected and remain a life-long source of infection for flock mates and their offspring (Herrmann-Hoesing et al., 2007).

The lentivirus of goats, caprine arthritis encephalitis virus (CAEV), is the closest relative of $\mathrm{VMV}$; together they are called small ruminant lentiviruses (SRLV). There is evidence of crossspecies transmission of VMV and CAEV between sheep and goats. With the exception of Australia and New Zealand, infection causes significant economic losses in sheep producing nations, such as Belgium, Canada, Denmark, Spain, Italy, Germany, Greece, Holland, Russia, South Africa and the USA (Peterhans et al., 2004; Reina et al., 2009).

Border disease (BD) is a congenital viral infection causing female infertility, abortion, stillbirths, and small, weak lambs. Reflecting the resulting congenital abnormalities and poor hair fleece quality, it is also known as "hairy shaker disease" or "fuzzy lamb syndrome" (Oğuzoğlu, 2008, Oğuzoğlu et al., 2009).

The disease is caused by BD virus (BDV), which is closely related to bovine viral diarrhoea virus (BVDV) and classical swine fever virus (CSFV). The virus is a member of the genus Pestivirus within the Flaviviridae family. The virion is spherical and 40-60nm in diameter while the genome consists of a single-stranded positivesense RNA (Maclachlan et al., 2011).

The virus is transmitted by secretion and excretion from both acutely and persistently infected animals (Oğuzoğlu, 2008). Vertical transmission is important in BD epidemiology as infection of fetuses in early gestation before their immune systems have developed may result in the birth of persistently infected lambs that become a potent source of infection and ensure the spread of virus within susceptible populations
(Burgu et al., 2001; Oğuzoğlu, 2008). Persistently infected offspring from homologous or heterologous strains with super-infection or virus mutation show increasing signs of mucosal disease (bronchopneumonia and ulcers in the digestive tract) (Herrmann-Hoesing et al., 2007; Oğuzoğlu, 2008).

This study aimed to determine the seroprevalance of VMV and BDV infection in sheep in and around Van province in eastern Turkey.

\section{MATERIALS AND METHODS}

A total of 360 serum samples were obtained from sheep brought to slaughterhouses in Van province (Figure 1). None of the sheep, which were either Akkaraman or Morkaraman species, had been vaccinated against VMV or BDV. The blood samples were centrifuged at 3,000RPM for 10 minutes and the serum was separated and preserved at $-20^{\circ} \mathrm{C}$ in preservation tubes until being tested using commercial kits according to the procedure provided by the company. Two specific commercial kits (IDEXX Chekit MVV/ CAEV P28 Antibody Test Kit, Screening Version, Switzerland; IDEXX Chekit BVDV/ MD/ BDV, P 80 Protein Antibody Test Kit, Screening Version, Switzerland) were used to detect VMV and BDV antibodies respectively.

Data analysis and determination of statistically significant differences between groups, with $\mathrm{P}<05$ accepted as significant, were performed using SPSS software.

\section{DISCUSSION}

Two of the most important persistent viral infections affecting small ruminant populations globally are VMV and BDV. The presence of persistently infected animals in flocks and the births of persistently infected offspring mean that flocks include animals without clinical signs of infection that continuously infect others, making it impossible to eliminate infection from the flock. In this study, weakness, retarded growth and various respiratory system problems were noticed in some of the sampled animals. Figures 2 and 3 show seropositivity rates for VMV and $\mathrm{BDV}$ in regions of Van province. Table 3 shows there were different ratios of seropositivity for both viruses in different towns in the province. 
Of the 360 samples tested for BDV, 149 sheep were Morkaraman species and 211 sheep were Akkaraman species. In Akkaraman sheep, 41.6\% (62/149) were seropositive while in Morkaraman species sheep, there were 47.8\% (101/211) seropositive samples. Chi square test showed that there was no significant difference in seropositivity rates between the two species $(\mathrm{P}>0.05)$. All the seropositive samples for VMV were from Akkaraman sheep.

VMV, which has a long incubation period, causes a slowly progressing, persistent infection that affects the lungs, brain, joints and mammary glands of sheep. The most important reason why the disease spreads is the sale of live animals, as first determined in Iceland and then in many European countries (Peterhans et al., 2004). Studies performed in Switzerland, Canada, Poland, Portugal, Morocco and the United States reported seropositivity rates of $9 \%, 19 \%, 24 \%$, 34.3\%, 24.8\% and 26\% respectively (Kita et al., 1990; Simard and Morley, 1991; Cutlip et al., 1992; Bouljihad and Leipold, 1994; Fevereiro, 1995; Schaller et al., 2000).

In Turkey, while VMV seropositivity was $0.02 \%$ according to pathological findings in slaughterhouses (Alibasoglu and Arda, 1975), the rate was reported as $23.9 \%$ using the AGID test (Burgu et al., 1990). Tan and Alkan (2002) reported a rate of $26.7 \%$ in which the virus was isolated from seropositive sheep to examine its persistence in animal tissue while Karaoglu et al. (2003) detected antibodies in $2.6 \%$ of samples from different regions in Turkey. In contrast, Muz et al. (2013) found seropositivity rates of $68.3 \%$ in samples from state-owned enterprises. This study, which is the first to examine infection rates in Van province, found seropositivity rates of $10.5 \%$ (Table 1 ).

Previous studies show that antibody response to VMV can occur intermittently after primary infection, and that the antibody response can be obtained in different titers in repeated samplings. Especially during pregnancy and lambing or in cases of immunosuppression, the virus titer can be increased and antibody response can change (De Andres et al., 2005).
While evaluating the antibody response against viruses in the Retroviridae family, the viruses' cycles of replication and pathogenesis should be considered as mutant genotypes may occur and field strains with antigenic variations may arise, especially during transcription and translation. These strains can avoid the immune system so the antigens used in the ELISA kit may not detect the specific antibodies generated against the virus, which leads to false-negative results (Burgu et al., 1990; De Andres et al., 2005). The serological response can be considered as a false negative in the early period when there is no antibody response in slow-developing virus infections (Reina et al., 2013).

Various studies have revealed the global distribution of Border Disease. Depending on the country and region, seroprevalence rates in sheep vary from $5 \%$ to $50 \%$ (Valdazo González et al., 2008). While clinical cases have been reported worldwide, the majority come from European countries (Pratelli et al., 1999). Using ELISA to investigate the presence of pestivirus antibodies in Australian samples, Krametter Froetscher et al. (2007) found seropositivity rates of $29.4 \%$.

BDV prevalence and economic losses from pestivirus have also been investigated in Turkey (Table 2). Seropositivity rates of $0.06-3 \%$ have been found, particularly in samples from aborted sheep (Burgu et al., 1987). Gür (2009) found pestivirus-specific antibodies in 78.5\% of sheep from seven flocks . Burgu et al. (2001) detected antibodies in pre-colostral blood samples of the lambs of 112 sheep, including 33 of 174 sheep sampled during the first and second months of pregnancy and at the time of birth, and 79 of 487 sheep sampled only at the time of birth. Using ELISA, Azkur et al. (2011) found seropositivuty rates of $74.51 \%$ accross all districts of Kirikkale province. Yavru et al. (2014) detected pestivirus antigens in $8.82 \%$ of fetuses and fetal tissue samples (liver, lung and brain). In the present study, the seropositivity rate for BDV was $45.2 \%$ in sheep (Table 2). This prevalence rate is very high considering that pestivirus plays an important role in causing abortion in sheep. 

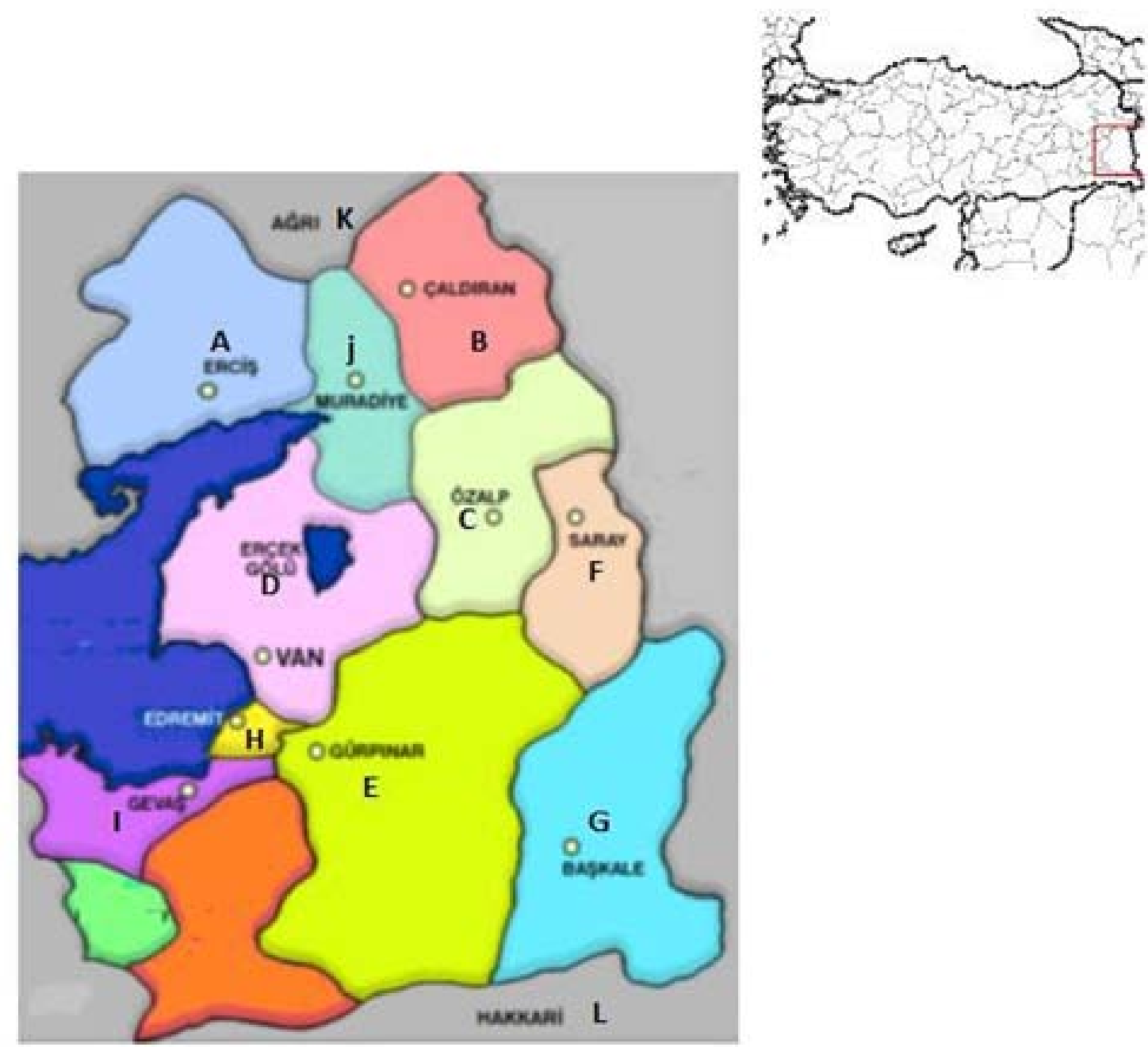

Figure 1. Regions where the sheep brought from and tested for diagnosis

Table 1. ELISA results of Visna-Maedi Virus serum samples

\begin{tabular}{cccc} 
Operating Code & Places & Number of serum samples & $\begin{array}{c}\text { Visna Maedi Virus } \\
(\%)\end{array}$ \\
\hline A & Erciş & 32 & $2(6.25)$ \\
B & Çaldıran & 29 & $8(27.58)$ \\
C & Özalp & 18 & - \\
D & Erçek & 46 & $7(15.21)$ \\
E & Gürpınar & 34 & - \\
F & Saray & 38 & - \\
G & Başkale & 30 & $9(30)$ \\
H & Edremit & 14 & - \\
I & Gevaş & 17 & - \\
J & Muradiye & 28 & - \\
K & Ağrı & 32 & $5(15.63)$ \\
L & Hakkari & 42 & $7(16.66)$ \\
Total & & 360 & $38(10.5)$ \\
\hline
\end{tabular}




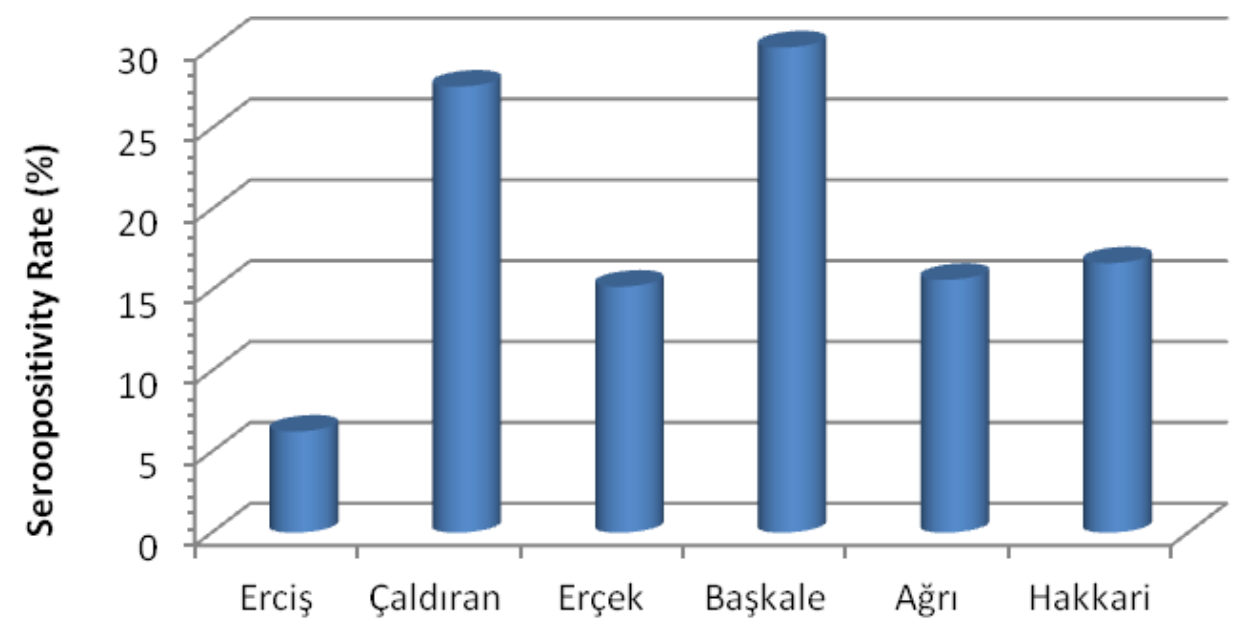

Figure 2. Seropositive ratio of Visna-Maedi virus in different regions belonging to Van province.

Table 2. ELISA results of Border disease virus (BDV) serum samples

\begin{tabular}{cccc}
$\begin{array}{c}\text { Operating } \\
\text { Code }\end{array}$ & Places & $\begin{array}{c}\text { Number of serum } \\
\text { samples }\end{array}$ & $\begin{array}{c}\text { Border Disease Virus } \\
(\%)\end{array}$ \\
\hline A & Erciş & 32 & $13(40.62)$ \\
B & Çaldıran & 29 & $9(31.03)$ \\
C & Özalp & 18 & $3(16.66)$ \\
D & Erçek & 46 & $25(54.34)$ \\
E & Gürpınar & 34 & $11(32.35)$ \\
F & Saray & 38 & $18(47.36)$ \\
G & Başkale & 30 & $14(46.66)$ \\
H & Edremit & 14 & $1(7.14)$ \\
I & Gevaş & 17 & $8(47.05)$ \\
J & Muradiye & 28 & $16(57.14)$ \\
K & Ağrı & 32 & $17(53.12)$ \\
L & Hakkari & 42 & $28(66.66)$ \\
Total & & 360 & $163(45.2)$ \\
\hline
\end{tabular}

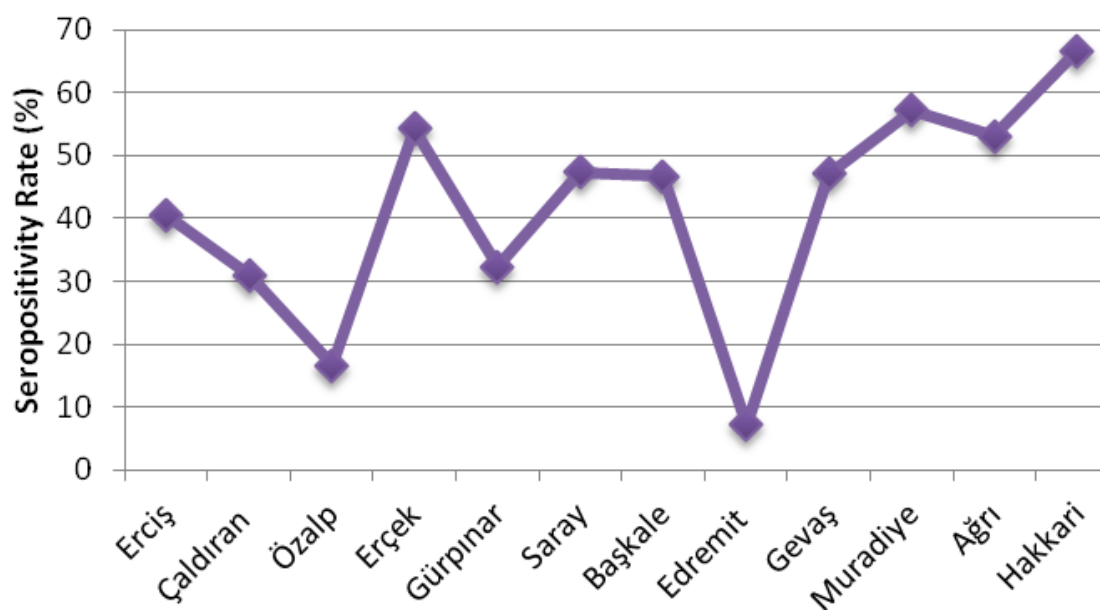

Figure 3. Border disease seropositive ratio according to the experiment centers belonging to Van province. 
Table 3. Results of Visna-Maedi Virus and Border Disease Virus seropositive samples

\begin{tabular}{cccccc}
$\begin{array}{c}\text { Operating } \\
\text { Code }\end{array}$ & Places & $\begin{array}{c}\text { Number of } \\
\text { serum samples }\end{array}$ & $\begin{array}{c}\text { Visna Maedi } \\
\text { Virus (\%) }\end{array}$ & $\begin{array}{c}\text { Border Disease } \\
\text { Virus (\%) }\end{array}$ & $\begin{array}{c}\text { VMV / BDV } \\
(+)\end{array}$ \\
\hline A & Erciş & 32 & $2(6.25)$ & $13(40.62)$ & - \\
B & Çaldıran & 29 & $8(27.58)$ & $9(31.03)$ & 3 \\
D & Merkez & 46 & $7(15.21)$ & $25(54.34)$ & 2 \\
G & Başkale & 30 & $9(30)$ & $14(46.66)$ & 4 \\
K & Ağrı & 32 & $5(15.63)$ & $17(53.12)$ & 3 \\
L & Hakkari & 42 & $7(16.66)$ & $28(66.66)$ & 5 \\
Total & & 211 & 38 & 106 & 17 \\
\hline
\end{tabular}

One of the major transit routes for Border Disease is via semen as large amounts of virus are distributed along with the semen of rams, which decreases the fertility rates of the virus. The rate of formation of persistent infection is low in rams so monitoring rams used in natural breeding is crucial to prevent infections spreading (Oguzoglu, 2008).

Studies of enterprises where sheep and cattle are grown together find seropositivity rates for antibodies against BDV and BVDV of $60-90 \%$ (Steck et al., 1980). The present study only sampled sheep so the presence of pestivirus antibodies could not be detected in cattle. Considering cross-species virus transmission, it is important to investigate the presence of pestivirus antibodies in enterprises where sheep and cattle are grown together. Serological studies should be supported by virological studies to determine the antigenic characterization of circulating virus strains. This would make an important contribution to animal husbandry and vaccine selection.

The present study found similar results to those of other studies for VMV and BDV rates, which may be due to the presence of persistently infected animals. Seroprevalence rate can also be increased if the animals sampled are older and by sampling during the lambing period (Nettleton, 1990; Herrmann Hoesing et al., 2007).

In Turkey, Eastern Anatolia has significant potential for sheep farming, whether family-scale or in large enterprises. The presence of persistently infected animals and pregnancies resulting in the birth of persistently infected offspring cause flocks to contain animals that show no clinical signs but continuously infect other animals, which make it impossible to eliminate infection. Moreover, because both infections cause abortions and fetal death, they are among the viral diseases responsible for the greatest economic losses in sheep farming.

\section{CONCLUSION}

BDV and VMV, which are common in small ruminant flocks worldwide including Turkey, are important due to the economic losses they cause. By providing data on infection rates in Van province, this study can stimulate further research and encourage more effective eradication measures. Important steps to eradicate these two infections include awareness raising among animal owners and veterinarians to enable proper identification of persistently infected animals, their removal from flocks, further studies and the development of effective eradication programs.

\section{ACKNOWLEDGEMENT}

This work, was supported 2015-SBE-YL318 project by Yüzüncü Yıl University Scientific Research Projects the Presidency and summarized from the master's thesis.

\section{REFERENCES}

ALİBAȘOGLU, M.; ARDA, M. Koyun pulmoner adenomatozisi'nin Türkiye'de durumu ile patolojisi ve etiyolojisinin araştırılması. [Türkiye]: Tübitak Vhag Yayınlar1, 1975. [274p].

AZKUR, A.K.; GAZYAGCI, S.; ASLAN, M.E.; UNAL, N. Molecular and serological characterization of pestivirus infectionamong sheep in Kirıkkale, Turkey. Kafkas Univ. Vet. Fak. Derg., v.17, p.83-92, 2011.

BOULJIHAD, M.; LEIPOLD, H.W. Ovine lentiviral infection (maedi/visna) in Morocco: a serologic and postmortem survey. Zentralbl Vet. A, v.41, p.317-328, 1994. 
BURGU, I.; AKCA, Y.; ALKAN, F. et al. The serological and virological investigations and pathogenesis of BVDV infection in sheep during preand post-partum periods. Turk. J. Vet. Anim. Sci., v.25, p.551-558, 2001.

BURGU, İ.; ÖZTÜRK, F.; AKCA, Y. et al. Investigations on the occurence and impact of bovine viral diarrhea (BVD) virus infections in sheep in Turkey. Dtsch. Tierärztl. Wschr., v.94, p.292-294, 1987.

BURGU, İ.; TOKER, A.; AKC, A Y. et al. Türkiye'de visna-maedi enfeksiyonunun serolojik olarak aras, tırılması Ankara Üniv. Vet. Fak. Derg., v.37, p.538-553, 1990.

CUTLIP, R.C.; LEHMKUHL, H.D.; SACKS, J.M.; WEAVER, A.L. Seroprevalance of ovine progressive pneumonia virus in sheep in the United States as assessed by analyses of voluntarily submitted samples. Am. J. Vet. Res., v.53, p.976-979, 1992.

DE ANDRÉS, D.; KLEIN, D.; WATT, N.J. et al. Diagnostic tests for small ruminant lentiviruses. Vet. Microbiol., v.107, p.49-62, 2005.

FEVEREIRO, M. Prevalance of maedi-visna infection in sheep in Portugal. Rev. Port. Cienc Vet., v.90, p.6670,1995.

GÜR, S. A investigation of border disease virus in sheep in Western Turkey. Trop. Anim. Health Prod., v.41, p.1409-1412, 2009.

HERRMANN HOESING, L.; PALMER, G.; KNOWLES, D. Evidence of proviral clearance following postpartum transmission of an ovine lentivirus. Virology, v.362, p.226-234, 2007.

KARAOĞLU, T.; ALKAN, F.; BURGU, İ. Küçük aile işletmelerindeki koyunlarda maedi-visna enfeksiyonunun seroprevalansı. Ankara Üniv. Vet. Fak. Derg., v.50, p.123-126, 2003.

KITA, J.; CUTLIP, R.C.; KENPSKI, W.; SACHS, J. Survey for antibodies against maedi visna in sheep in Polands. Pol. Arch. Weter., v.30, p.5-11, 1990.

KRAMETTER FROETSCHER, R.; KOHLER, H.; BENETKA, V. et al. Influence of communal alpine pasturing on the spread of pestiviruses among sheep and goats in Austria: first 1dentification of border disease virus in Austria. Zoonoses Public Health, v.54, p.209-213, 2007.

MACLACHLAN, N.; DUBOVI, E.; FENNER, F. Fenner's veterinary virology. Amsterdam: Elsevier Academic Press, 2011. 534p.

MCNEILLY, T.; BAKER, A.; BROWN, J. et al. Role of alveolar macrophages in respiratory transmission of visna/ Maedi virus. J. Virol., v.82, p.1526-1536, 2008.
MUZ, D.; OĞUZOGLU, T.C.; ROSATİ, S. et al. First molecular characterization of visna/maedi viruses from naturally infected sheep in Turkey. Arch. Virol,. v.158, p.559-570, 2013.

NETTLETON, P.; Pestivirus infections in ruminants other than cattle. Rev Sci Tech, v.9,p.131-150, 1990.

OĞUZOĞLU, T.C. Sınır hastalığı (Border disease). Ankara Üniv. Vet. Fak. Derg., v.55, p.69-74, 2008.

OĞUZOĞLU, T.C.; TAN, M.T.; TOPLU, N. et al. Border disease virus (BDV) infections of small ruminants in Turkey: a new BDV subgroup. Vet. Microbiol., v.135, p.374-379, 2009.

PETERHANS, E.; GREENLAND, T.; BADIOLA, J. et al. Routes of transmission and consequences of small ruminant lentiviruses (SRLVs) infection and eradication schemes. Vet. Res., v.35, p.257-274, 2004.

PRATELLI, A.; BOLLO, E.; MARTELLA, V. et al. Pestivirus infection in small ruminants: virological and histopathological findings. New Microbiol., v.22, p.351-356, 1999.

REINA, R.; BERRIATUA, E.; LUJAN, L. et al. Prevention strategies against small ruminant lentiviruses: an update. Vet. J., v.182, p.31-37, 2009.

REINA, R.; DE ANDRÉS, D.; AMORENA, B. Immunization against small ruminant lentiviruses. Viruses, v.5, p.1948-1963, 2013.

SCHALLER, P.; VOGT, H.R.; STRASSER, M. et al. Seroprevalance of maedi-visna virus and border disease in Switzerland. Schweiz. Arch. Tierheilk., v.142, p.145-153, 2000.

SIMARD, C.; MORLEY, R. Seroprevalance of maedivisna in Canadian sheep. Can. J. Vet. Res., v.55, p.269-273, 1991.

STECK, F.; LAZARY, S.; FEY, H. et al. Immune responsiveness in cattle fatally affected by bovine virus diarrhea-mucosal disease. Zentralbl. Vet. Med., v.27, p.429-445, 1980.

TAN, M.T.; ALKAN, F. Türkiye'de visna-maedi enfeksiyonunun seroepidemiyolojisi ve virus izolasyonu. Ankara Üniv. Vet. Fak. Derg., v.49, p.4550, 2002.

THORMAR, H. The origin of lentivirus research: maedi-visna virus. Curr. HIV Res., v.11, p.2-9, 2013

VALDAZO GONZÁLEZ, B.; ALVAREZ, M.; SANDVIK, T. Prevalence of border disease virus in Spanish lambs. Vet. Microbiol., v.128, p.269-278, 2008.

YAVRU, S.; AVCI, O.; ATLI, K. Koyun fötuslarında border disease virus varlığının immunperoksidaz ile saptanmasi. Eurasian J. Vet. Sci., v.30, p.222-226, 2014. 